\title{
Macroinfaunal recovery on the beach most severely affected by the 'Prestige' oil spill (O Rostro, Galicia, north-west Spain)
}

\author{
J. JUNOY ${ }^{1,2}$, C. CASTELLANOS ${ }^{1}$, R. BERNARDO-MADRID ${ }^{1}$, R. RIERA ${ }^{3}$ AND J.M. VIÉITEZ ${ }^{1}$ \\ ${ }^{1}$ Departamento de Ciencias de la Vida, Universidad de Alcalá, E-28871 Alcalá de Henares, Spain, ${ }^{2}$ UE-US Marine Biodiversity \\ Research Group, Instituto Franklin, Universidad de Alcalá, E-28871 Alcalá de Henares, Spain, ${ }^{3}$ Centro de Investigaciones \\ Medioambientales del Atlántico (CIMA SL), Arzobispo Elías Yanes 44, E-38206 La Laguna, Tenerife, Canary Islands, Spain, \\ Present address: Department of Biodiversity, Qatar Environment and Energy Research Institute (QEERI), 5825 Doha, Qatar
}

\begin{abstract}
Exposed sandy beaches are widespread coastal habitats with temporal and spatial variability. O Rostro beach (Galicia, northwest Spain) was the most severely affected beach in the 'Prestige' oil spill (November 2002). Monitoring sampling was conducted to study macroinfaunal composition and structure after the oil spill episode. The purpose of this survey was to characterize macroinfaunal variations on the beach over a yearly scale (2003-2007) and determine the recovery period. These data are compared with the only available data collected before the spill (1995). Two zones where identified with different recovery trends: (1) supralittoral, occupied either by talitrid amphipods, oniscoidean isopods and insects; and (2) intertidal, where marine crustaceans prevailed. Beach morphodynamics partially buried the oil, which gradually reappeared and was dragged to the coast. Negative ecological effects were observed in the short term (six months after the 2002 spill) but macroinfauna apparently recovered in the following years (2004-2007), showing that macroinfaunal assemblages of this beach are resilient enough to recover after severe stress.
\end{abstract}

Keywords: oil-spill, 'Prestige', beach, macroinfauna, Galicia, Atlantic Ocean

Submitted 18 February 2013; accepted 6 September 2013; first published online 14 October 2013

\section{INTRDDUCTION}

Exposed beaches are considered poor habitats, where wave action and sediment instability limit the development of biological assemblages, with low productivity compared with other coastal environments (McLachlan, 1983). Species on sandy beaches are related to both interstitial moisture levels in sand at low tide and tide levels or inundation times (McLachlan, 1990; Jaramillo et al., 1993). In temperate latitudes, supralittoral levels are usually occupied by an assemblage formed by semi-terrestrial amphipods (talitrids), isopods (Oniscidea) and insects (mainly dipterans and coleopterans) that is linked to the food supply from algal wrack and tidal organic material (Jaramillo et al., 1993; McLachlan \& Jaramillo, 1995). Intermediate intertidal levels are usually occupied by marine isopods (cirolanids) and polychaetes (spionids) (Junoy \& Viéitez, 1992; Souza \& Borzone, 2000) Lower intertidal levels are occupied by marine amphipods, isopods, cumaceans, polychaetes and molluscs (Jaramillo, 1994; McLachlan \& Jaramillo, 1995).

Oil-spills are considered one of the most significant environmental disasters on intertidal coastal areas and, particularly, the 'Prestige' oil-spill off north-west Spain in November 2002 was especially harmful due to its magnitude

Corresponding author:

J. Junoy

Email: juan.junoy@uah.es
(Puente et al., 2009). The oil spill motivated many ecological studies on affected intertidal beaches and estuaries, with special emphasis on macroinfaunal assemblages (de la Huz et al., 2005; Junoy et al., 2005; Puente et al., 2008, 2009). Natural variability of exposed beaches depends on different factors, such as slope, tidal ranges, biogeography, latitude and food supply, as well as seasonal cycles that comprise water temperature, storm events, wave exposure and accretion-erosion dynamics (Brazeiro \& Defeo, 1996; Lastra et al., 2006). Medium and long-term studies are suitable to differentiate between the rates of natural and/or anthropogenic disturbances, but these studies are scarce on sandy beaches. To our knowledge, there are no long-term studies on macroinfaunal assemblages from beaches considering natural inter-annual variability and an episodical anthropogenic disturbance (e.g. an oil spill).

The present environmental study was conducted at O Rostro beach, the beach most affected by the 'Prestige' oil spill and previously characterized by very low macroinfaunal abundance and diversity (Junoy et al., 2005; Lastra et al., 2006). The beach morphodynamic is well known after the monitoring plan and studies developed since the 'Prestige' catastrophe (Bernabeu et al., 2006; CEPRECO 2006; González et al., 2009).

The main aims of the present work were to analyse: (i) the short-term effects of the 'Prestige' oil spill on macroinfaunal assemblages; and (ii) to determine the macroinfaunal recovery in the most affected beach in Spain after the oil spill over the medium term (2003-2007). 


\section{MATERIALS AND METHDDS}

\section{Study area and sampling procedure}

The study was conducted at $\mathrm{O}$ Rostro beach $\left(42^{\circ} 58^{\prime} \mathrm{N}\right.$ $9^{\circ} 15^{\prime} \mathrm{W}$ ), located on the Galician Costa da Morte (northwest Spain; Figure 1A). The beach is $2000 \mathrm{~m}$ long, laterally confined at both sides by cliffs. The intertidal width is up to $150 \mathrm{~m}$ for spring tides; the supralittoral comprises a sandbank without vegetation (50 m wide) and a vegetated dune system (100 $\mathrm{m}$ wide; Figure $1 \mathrm{~B}$ ). O Rostro beach is exposed to large waves (Bernabeu et al., 2006; CEPRECO, 2006). The tidal range in spring is up to $4.5 \mathrm{~m}$. It is an intermediate beach, with a stable middle-scale transversal bar-horn system (González et al., 2009). In contrast with other Spanish beaches, it is a non-urbanized beach with few recreational users.

As a result of the sinking of the 'Prestige' tanker, oil reached O Rostro beach on 18 November 2002. The beach received a significant amount of oil throughout 2003 and was the beach most polluted by the 'Prestige; $>10,000 t$ of residual material were removed from the beach (Junoy et al., 2005; González et al., 2009). Buried oil also gradually reappeared and was dragged to the coast because of the beach morphodynamic (Bernabeu et al., 2006; CEPRECO, 2006; González et al., 2009). Six months after the spill (May 2003), big tar balls $(15-30 \mathrm{~cm}$ diameter) were obvious in the sediment (Figure $1 \mathrm{C}$ ) and small pellets $(1-2 \mathrm{~cm})$ were collected as late as May 2007 (Figure 1D).

This beach was surveyed throughout five sampling campaigns; six months after the oil spill (May 2003), when cleaning activities were finished and sampling was authorized, and for four years after the oil spill (May 2004, May 2005, May 2006 and May 2007). The campaigns sampled two transects in the middle of the beach which extended from above the drift line (supralittoral) to below the swash line. Beach division was based on Salvat's zonation scheme (Salvat, 1964, 1967) adding an extra supralittoral level (Pollock \& Hummon, 1971). Hence, five levels were sampled in each transect, two levels at supralittoral zone: (1) $2 \mathrm{~m}$ above the drift line; and (2) at the drift line; and three levels in the intertidal zone: (3) retention, tidal level 3-2 m; (4) resurgence, tidal level 2-1 m; and (5) saturation, tidal level 1-o m. At each level, three $0.05 \mathrm{~m}^{2}$ replicates (1 $\mathrm{m}$ apart) were taken with plastic cylinders to a depth of $30 \mathrm{~cm}$ and sieved through a $1 \mathrm{~mm}$ mesh. The retained residue in the mesh sieve was preserved in $7 \%$ formaldehyde; macroinfauna was subsequently sorted from the sediment, identified and counted. The level of replication was based on previous studies (De la Huz, 2005; Junoy et al., 2005).

A classical BACI design (Before-After-Control-Impact; Underwood, 1991) was impossible to perform, due to the lack of data before the oil spill and suitable controls, i.e. unaffected beaches with similar environmental characteristics. The only available macroinfaunal data from $\mathrm{O}$ Rostro beach were collected on only one sampling occasion (September, 1995) seven years before the spill (Lastra et al., 2006). These data were used as reference for the previous beach state.

The AZTI Marine Biotic Index (AMBI) (www.ambi.azti.es) was designed to establish the ecological quality of European coasts, investigating the response of soft-bottom communities to natural and human-induced changes (Borja et al., 2000), being verified successfully in relation to a very large set of environmental impact sources (Borja et al., 2003). The AMBI
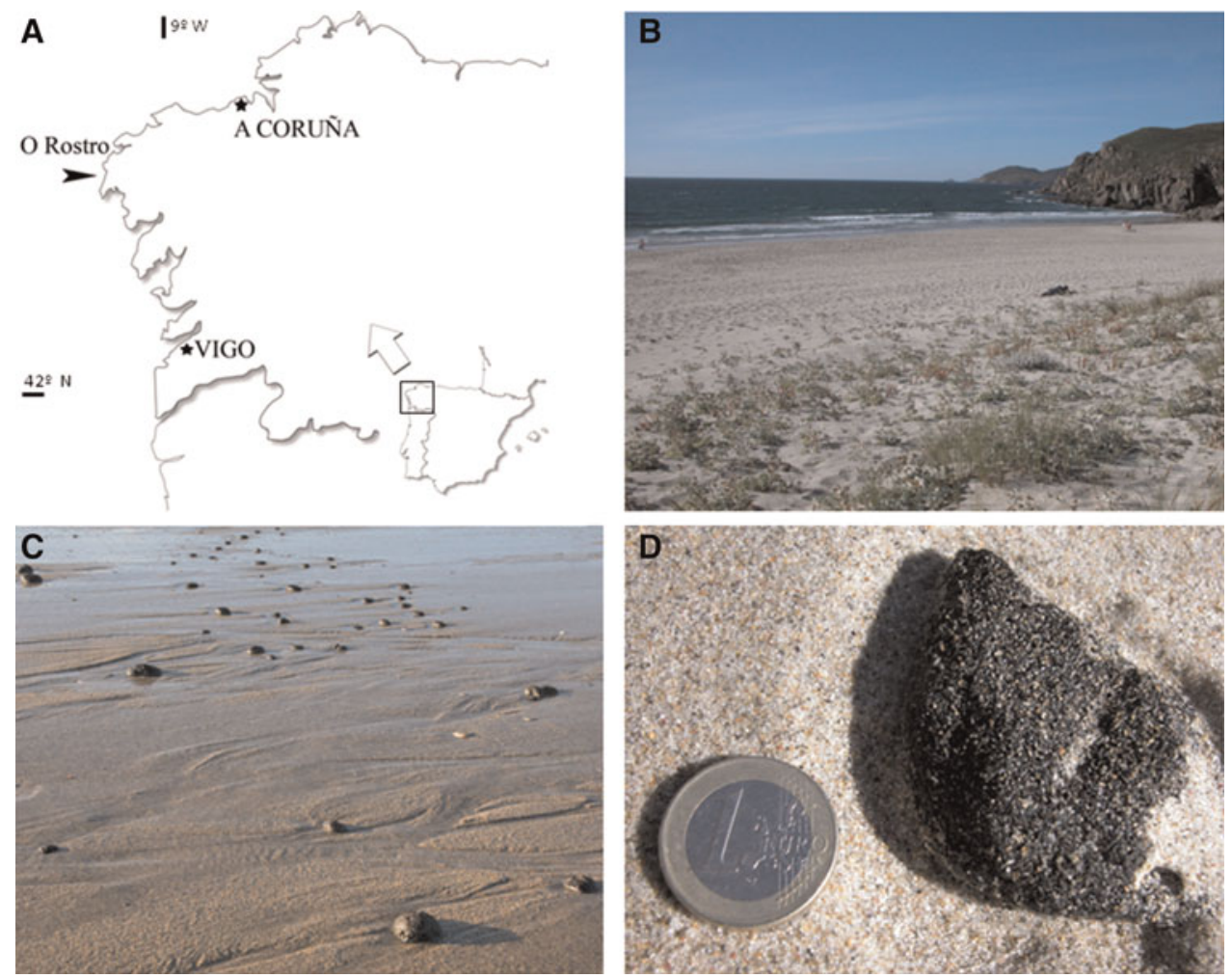

Fig. 1. (A) Location of the O Rostro beach; (B) photograph of the north end of the O Rostro beach at high tide on May 2003 ; (C) tar balls (15-30 $\mathrm{cm}$ diameter) observed at the intertidal on first sampling campaign (May 2003); (D) small pellets still present at O Rostro beach at the last sampling campaign (May 2007). 
was used exclusively for evaluation of the intertidal zone; supralittoral species were mainly excluded from the species list.

\section{Environmental variables}

At each sampling level, one sediment sample was collected for grain size analysis and organic matter content. The sediment was labelled and kept in plastic bags until its arrival at the laboratory, where it was dried in a stove at $60^{\circ} \mathrm{C}$ for $24 \mathrm{~h}$ to constant weight. Particle size analysis was performed by dry sieving (Buchanan, 1984). Organic matter content of the sediment was estimated as weight loss of dry samples after combustion $\left(450^{\circ} \mathrm{C}, 24 \mathrm{~h}\right)$. During the 2004 campaign, six sediment samples at each sampling level were used to determine the concentration of hydrocarbons in the sediment with the field kit PetroFlag (Dexsil, Hamden, USA). The oil was buried randomly at the beach and the measurements were highly variable. The method was discarded for the following campaigns.

At each sampling occasion, beach slope $(S=1 / R$, where $R=$ intertidal width/height of the upper intertidal level) was estimated by the Emery method (Emery, 1961); wave height and wave period were estimated to calculate Dean's parameter $(\Omega)$ according to Short (1999). Furthermore, the beach index (BI) was calculated as follows

$$
\left[\mathrm{BI}=\log _{10}(\mathrm{Mz} \times \mathrm{TR}) / S\right]
$$

where TR is the tidal range, $S$ is the beach slope and $\mathrm{Mz}$ is the mean particle size expressed in ( $\varphi$ units +1$)$, to avoid negative values (McLachlan \& Dorvlo, 2005). These data were largely completed during morphodynamic beach studies after the oil spill (CEPRECO, 2006; González et al., 2009).

\section{Statistical analysis}

Macroinfaunal assemblages for each time of sampling were analysed using the multivariate package PRIMER v. 6 (Clarke \& Gorley, 2006). Multivariate data were square root transformed to retain information regarding relative abundances and to reduce differences in scale among the variables (i.e. Clarke \& Green, 1988) and Bray-Curtis dissimilarity matrices were calculated between all pairs of samples for ensuing analyses (Bray \& Curtis, 1957). To avoid possible fluctuations due to near-blank samples, a dummy was added to conduct the zero-adjusted Bray-Curtis dissimilarity (Clarke \& Gorley, 2006). PERMDISP analyses (Anderson, 2005) for testing the homogeneity of multivariate dispersions was previously performed. PERMANOVA analysis was used to study the differences between 'year', 'level' and the interaction 'year $\times$ level'. An unconstrained ordination, non-metric multidimensional scaling (nMDS) (Kruskal \& Wish, 1978) and cluster analyses were performed to show multivariate patterns among plots.

Statistical methods available in Systat 12 (SPSS, 1999) were performed to analyse macroinfaunal and sedimentary data as a function of year $(2003-2007)$ and tidal zone (supralittoral vs intertidal). Factor analysis (FA) was used to look for coherent grain size groups of variables that were correlated with one another within groups but largely independent between groups (Tabachnick \& Fidell, 2001). These groups of correlated variables or factors help to interpret the underlying mechanisms that have created the relationship between variables. To facilitate interpretation, varimax rotation was used, since it minimizes the number of variables that load highly on a factor and maximizes the loading variance across factors. To further facilitate the interpretation of correlation, analyses were employed between those granulometric variables loading high in the factors and their associated macroinfaunal species.

\section{RESULTS}

\section{Environmental variables}

Sedimentary characteristics of the O Rostro beach throughout the study period are given in Table 1 . The dominant sedimentary type was medium sands $(0.2-0.5 \mathrm{~mm}$ diameter) throughout the study period in both zones (supralittoral and intertidal). Gravel and silt-clay were scarce $(<1.3 \%)$. Organic matter content was characterized by low concentrations $(<1.2 \%)$ (Table 1$)$. Data from the concentration of the hydrocarbons in the sediment varied from $36.50 \pm$ $17.79 \mathrm{ppm}$ at the upper supralittoral level to $139.18 \pm$ $63.22 \mathrm{ppm}$ at the saturation level.

Beach index (BI) ranged from 2.23 (2004) to 2.61 (2005). Dean's parameter $(\Omega)$ estimated at the sampling times ranged from 3.2 (2007) to 3.8 (2004). However, the beach slope $(1 / x)$ varied greatly at $O$ Rostro beach, from 21.85 (2004) to 48 (2006).

These observations are in concordance with the data of CEPRECO (2006) and González et al. (2009). These authors noted that the modal state of the beach corresponds to the 'Rhythmic Bar and Beach'; however, the beach exhibits a great temporal distribution of morphodynamic states, from 'Transversal Bar and Rip' to 'Longshore Bar and Trough'.

\section{Macroinfauna assemblage}

The overall macroinfaunal abundances varied largely throughout the study period, ranging from 49 ind. $\mathrm{m}^{2}$ (2005) to 280 ind. $\mathrm{m}^{2}$ (2007). These differences were mainly due to the variations of crustacean abundances, the dominant taxonomic group (Table 2). Species richness remained constant with slight variations throughout the study period, with the exception of 2003 campaign, six months after the spill, which showed the lowest richness (five taxa) (Table 2).

The supralittoral zone was characterized by low macroinfaunal abundance throughout the study period, ranging from 63 ind. $\mathrm{m}^{2}$ (2005) to 276 ind. $\mathrm{m}^{2}$ (2007) (Figure 2). The most abundant species were the talitrid amphipod Talitrus saltator ( 167 individuals), the isopod Tylos europaeus (141 individuals), the oligochaeta (114 individuals) and the talitrid Talorchestia brito (41 individuals). The remaining species were scarce $\left(<_{10}\right.$ individuals) (Table 2$)$.

Abundance of taxa at the intertidal zone varied largely throughout the study period, ranging from only 1 ind. $\mathrm{m}^{2}$ six months after the spill (2003) to a maximum 282 ind. $\mathrm{m}^{2}$ at the end of the study period (2007) (Figure 2). The most abundant species collected after the spill were the isopods Eurydice naylori (257 individuals), and the amphipod Pontocrates arenarius (250 individuals), followed by the mysid Gastrosaccus roscoffensis (61 individuals). As in the supralittoral zone, the remaining species were scarce ( $<10$ individuals). 
In 2003 post-oil spill conditions, macroinfaunal assemblages were represented by only one intertidal specimen of the amphipod Pontocrates arenarius and four supralittoral taxa: Oligochaeta, Tabanidae larvae, the coleopteran Hypocaccus dimidiatus maritimus and the isopod Tylos europaeus. Tylos europaeus dominated overwhelmingly (156 ind. $\mathrm{m}^{2}, 94.94 \%$ overall abundance), and together with the oligochaetes and Pontocrates arenarius were collected in all sampling campaigns (1995 and 2003-2007). Supralittoral talitrids Talitrus saltator and Talorchestia brito, and the mysid Gastrosaccus were collected at each sampling occasion, including 1995, except for 2003, six months before the spill.

The most abundant Eurydice species after the spill was E. naylori, an isopod species described in 1997 (Jones \& Pierpoint, 1997), and obviously not recorded in the 1995 sampling campaign. Polychaetes, represented by three spionid species, were scarce. Only two specimens of Scolelepis mesnili were collected in 2005 and 2007, whereas in 1995 the species collected were Scolelepis squamata and Spio filicornis.

\section{Analysis results}

Significant differences were found in the multivariate analyses of variance according to the factors 'zone' and 'year', with a $P$-value $($ perm $)<0.0001$ for the study period. A significant result was also found for the interaction of 'zone $\times$ year' $(P$ $($ Perm $)<0.0001)$ (Table 3$)$. These results were in concordance with a different test on the homogeneity of multivariate dispersion of the samples. The nMDS and cluster analyses of supralittoral and intertidal zones show that 2003 (six months after the spill) is separated from the remaining years (Figures 3 \& 4). The cluster analysis shows a close resemblance between 1995 and 2007 at both zones. Macroinfaunal assemblage structure remained almost constant throughout the study period.

A factor analysis (FA) was used with sediment variables and two factors were identified. Factor 1 comprises grain size, gravels and organic matter and Factor 2 includes siltclay and a sorting coefficient $\left(\mathrm{S}_{\mathrm{o}}\right)$ (Table 4 ). The percentage of variance explained for each factor is: $43.30 \%$ (axe 1) and $25.08 \%$ (axe 2), with a total of $68.38 \%$.

Significant correlations occurred only between factor 2 (silt-clay and the sorting coefficient $\left(\mathrm{S}_{\mathrm{o}}\right)$ ) and the amphipod Pontocrates arenarius (Pearson correlation $R=0.26 ; P=$ 0.043).

The temporal variation in the AMBI also shows the beach recovery after the impact. In 2003 the beach is classified as highly disturbed $(\mathrm{AMBI}=5.671)$, only slightly disturbed in the following year, $2004(\mathrm{AMBI}=2.887)$ and undisturbed in 2005, 2006 and 2007 (AMBI $=1.105,0.900$ and 0.603 , respectively). The beach was also considered undisturbed in $1995(\mathrm{AMBI}=0.950)$.

\section{DISCUSSION}

The main problem for the assessment of the ecological effects of the 'Prestige' oil spill is the lack of baseline studies in many of the ecosystems affected, as has been highlighted in other studies (Gelin et al., 2003; Puente et al., 2009). Previous data (1995) from Galician beaches made possible comparisons before and after the 2003 oil spill. In this context, a wide 
Table 2. Density (individuals $/ \mathrm{m}^{2}$ ), species richness and diversity of the macrofauna throughout the study period. ${ }^{*}, 1995$ data elaborated from original data provided by Dr Lastra (Universidad de Vigo); ${ }^{1}$, Eurydice naylori was described in 1997 and is obviously absent from the 1995 data; ${ }^{2}$, the specie was Gastrosaccus roscoffensis in the 2003-2007 sampling campaigns.

\begin{tabular}{|c|c|c|c|c|c|c|c|c|c|c|c|c|c|}
\hline \multirow[b]{2}{*}{ Group } & \multirow[b]{2}{*}{ Species } & \multicolumn{2}{|l|}{$1995^{*}$} & \multicolumn{2}{|l|}{2003} & \multicolumn{2}{|l|}{2004} & \multicolumn{2}{|l|}{2005} & \multicolumn{2}{|l|}{2006} & \multicolumn{2}{|l|}{2007} \\
\hline & & Supra- & Inter- & Supra- & Inter- & Supra- & Inter- & Supra- & Inter- & Supra- & Inter- & Supra- & Inter- \\
\hline Oligochaeta & Oligochaeta sp. & 5.0 & o & 1.6 & 0 & 106.6 & 1.1 & 11.6 & o & 55.0 & 22.2 & 8.3 & 0 \\
\hline Polychaeta & Scolelepis mesnili & o & o & 0 & 0 & 0 & 0 & o & 1.1 & o & o & o & 1.1 \\
\hline Polychaeta & Scolelepis squamata & o & 4.4 & o & 0 & o & o & 0 & 0 & 0 & o & o & 0 \\
\hline Polychaeta & Spio filicornis & o & 1.6 & o & 0 & o & o & 0 & 0 & o & 0 & 0 & 0 \\
\hline Amphipoda & Pontocrates arenarius & o & 22.7 & o & 1.1 & 0 & 104.4 & 0 & 18.8 & 0 & 58.8 & 0 & 94.4 \\
\hline Amphipoda & Talitrus saltator & 11.6 & 0 & o & o & 60.0 & o & 1.6 & o & 21.6 & o & 195.0 & o \\
\hline Amphipoda & Talorchestia brito & 36.6 & o & o & 0 & o & o & 8.3 & o & $13 \cdot 3$ & o & 45.0 & o \\
\hline Amphipoda & Talorchestia deshayesii & 23.3 & o & o & 0 & 1.6 & o & o & o & o & o & 1.6 & 0 \\
\hline Isopoda & Eurydice affinis & o & 1.6 & o & o & o & o & 0 & 0 & o & o & o & 1.1 \\
\hline Isopoda & Eurydice naylori $^{1}$ & - & - & o & 0 & o & 25.5 & 0 & $33 \cdot 3$ & o & 61.1 & 0 & 165.5 \\
\hline Isopoda & Eurydice pulchra & 0 & 208.8 & 0 & 0 & o & o & 0 & 1.1 & 0 & 6.6 & o & 1.1 \\
\hline Isopoda & Tylos europaeus & 28.3 & 0 & 156.6 & o & $3 \cdot 3$ & 0 & 15.0 & o & 48.3 & o & 11.6 & o \\
\hline Isopoda & Lekanesphaera welli & o & o & o & o & o & 2.2 & o & o & o & o & o & o \\
\hline Mysida & Gastrosaccus sp. ${ }^{2}$ & o & 25.5 & o & 0 & o & 45.5 & o & 2.2 & o & 1.1 & o & 18.8 \\
\hline Decapoda & Portumnus latipes & o & 0 & o & o & o & 1.1 & 0 & o & o & o & o & o \\
\hline Insecta & Cafius xantholoma & o & o & o & o & o & o & o & o & 1.6 & o & o & o \\
\hline Insecta & Hypocaccus dimidiatus maritimus & o & o & $3 \cdot 3$ & o & o & o & o & o & 5.0 & o & o & o \\
\hline Insecta & Coccinelidae & 0 & o & o & o & o & o & o & o & 1.6 & o & 0 & 0 \\
\hline Insecta & Tabanidae & 5.0 & o & 1.6 & o & o & o & 1.6 & o & 0 & o & 6.6 & 0 \\
\hline Insecta & Diptera sp. & 15.0 & o & 0 & 0 & 0 & 0 & o & o & o & o & 8.3 & 0 \\
\hline Nemertea & Psammamphiporus elongatus & o & 0 & o & o & o & $3 \cdot 3$ & o & o & o & 0 & o & 0 \\
\hline Nemertea & Nemertea sp. & o & 5.5 & 0 & o & 0 & 0 & 0 & o & 0 & $3 \cdot 3$ & 0 & 0 \\
\hline Species richness & & 1.39 & 1.63 & 0.65 & - & 0.64 & 1.17 & 1.27 & 1.07 & 1.34 & 1.04 & 1.17 & 1.08 \\
\hline Shannon diversity $\left(\log _{2}\right)$ & & 2.51 & 1.29 & 0.30 & o & 1.13 & 1.62 & 1.92 & 1.38 & 2.09 & 1.54 & 1.45 & 1.41 \\
\hline
\end{tabular}

Table 3. Results of PERMANOVA testing for diffferences in macrofaunal assemblage structure throughout the study period with Year and Zone as fixed factors.

\begin{tabular}{lrlccc}
\hline Source & df & SS & MS & Pseudo-F & P (perm) \\
\hline Year & 5 & 56,154 & 11,231 & 9.6102 & 0.0001 \\
Zone & 1 & 64,794 & 64,794 & 55.444 & 0.0001 \\
Year $\times$ Zone & 5 & 30,615 & 6123.1 & 5.2395 & 0.0001 \\
Residual & 168 & $1.963_{\mathrm{E}} 5$ & 1168.6 & \\
Total & 179 & $3.516_{\mathrm{E} 5}$ & & & 9951 \\
\hline
\end{tabular}

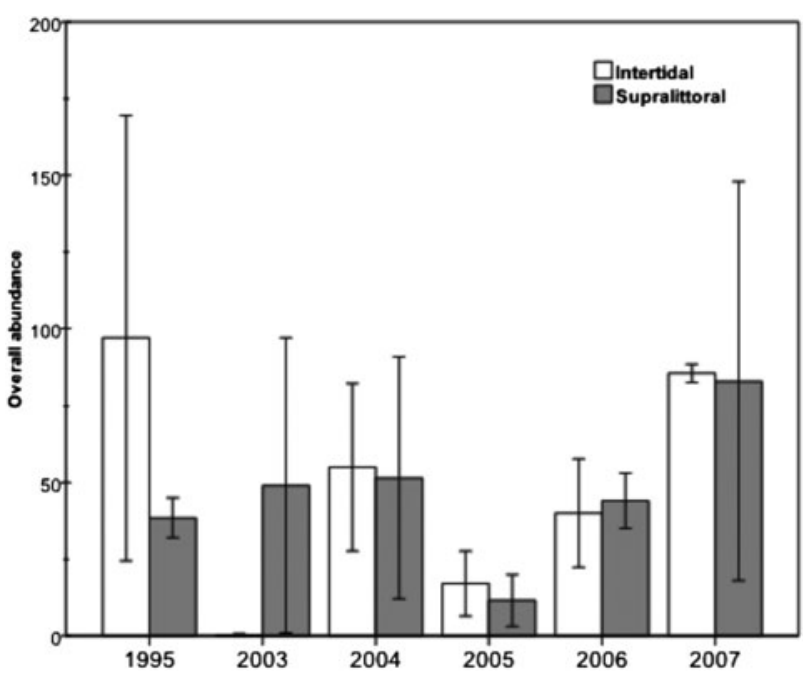

Fig. 2. Overall macrofaunal abundances $( \pm S E)$ in intertidal and supralittoral stations throughout the study period (oil spill started November 2002). spatial analysis, with many beaches sampled, has proved to be useful in detecting the general impact in short term beforeafter analyses (De la Huz et al., 2005; Junoy et al., 2005). A reduction of macroinfaunal abundance and species richness was encountered six months after the spill. These shifts were particularly accentuated in scarce species, represented by low abundance at the studied beaches, which were eliminated from oiled beaches (De la Huz et al., 2005; Junoy et al., 2005). In the supralittoral, macroinfaunal variations consisted of the disappearance of insects, and in some cases, a sharp increase of oligochaetes. This increase was related to the oil deposit at upper beach level. Talitrid amphipods and the isopod Tylos europaeus showed a clear reduction in abundance. In the intertidal zone, a marked decrease of polychaetes and isopods abundance (Scolelepis spp., Eurydice spp.) and the increase of abundance of the amphipod Pontocrates arenarius was observed.

Talitrids and Eurydice spp. were absent in the samples six months after the spill (2003). The increase of Pontocrates arenarius abundance observed in 2003 at Galician beaches (Junoy 
A

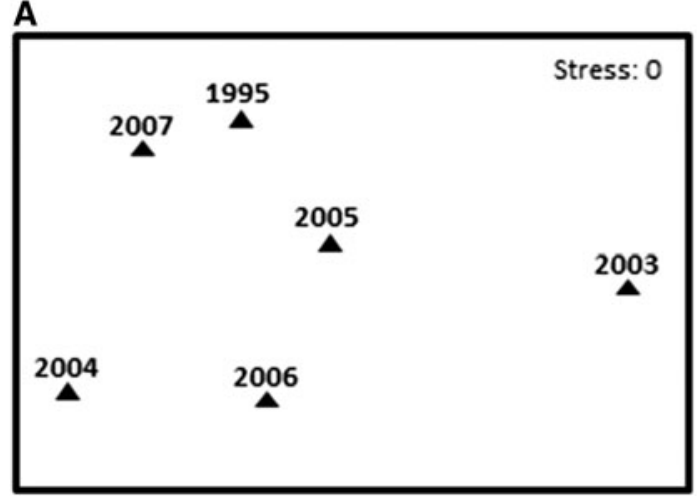

B

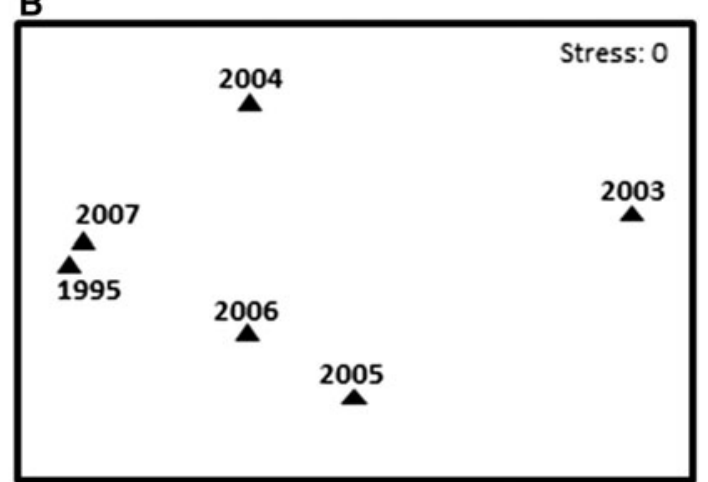

Fig. 3. Non-metric multidimensional scaling similarity plot computed for: (A) supralittoral; (b) intertidal.

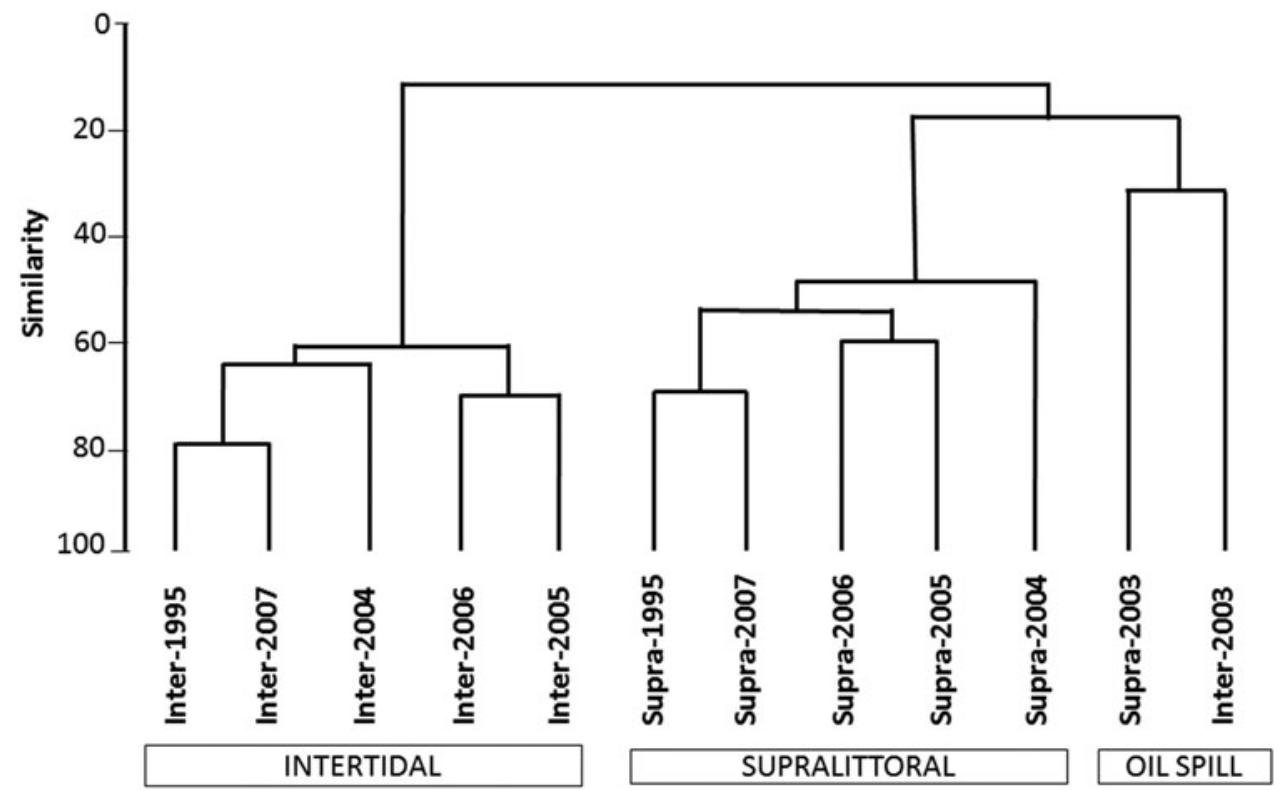

Fig. 4. Cluster analysis for the supralittoral and intertidal zones at the different sampling campaigns. First campaign, May 2003, is labelled OIL SPILL.

et al., 2005) was also evident in 2004 at O Rostro beach. Junoy et al. (2005) noted that with the available data it was difficult to assess whether $P$. arenarius is an opportunistic species favoured by the 'Prestige' spill, but it is noteworthy that in the most severely affected beach the increase was delayed. Scolelepis species were always rare at O Rostro due to the sedimentary characteristics of the beach; both S. squamata and S. mesnili prefer finer sediments (Laborda, 1987; Junoy \& Viéitez, 1992).

The 'Prestige' oil spill did not markedly affect macroinfaunal diversity and richness (De la Huz et al., 2005; Serrano

Table 4. Factor analysis with sedimentary variables.

\begin{tabular}{lrr}
\hline & Factor 1 & Factor 2 \\
\hline Grain size & 0.893 & -0.074 \\
Gravels (\%) & 0.824 & 0.175 \\
Organic matter (\%) & 0.634 & 0.190 \\
Silt/clay (\%) & -0.042 & 0.895 \\
S $_{\text {o }}$ & 0.286 & 0.895 \\
\hline
\end{tabular}

et al., 2006; Puente et al., 2009), which was observed in other oil spills (Kingston et al., 1995; Feder \& Blanchard, 1998; Fukuyama et al., 1998). A significant effect observed in other spills (Pielou, 1975; Gómez-Gesteira et al., 2003) was an enhanced abundance of opportunistic species, mainly polychaetes, accompanied by a sharp decrease of sensitive species, mainly amphipods (Gómez-Gesteira \& Dauvin, 2000, 2005; Peterson, 2001). This smaller effect of the 'Prestige' oil spill could be explained by the physico-chemical characteristics of the oil, the season of the spill (winter), rough seas, sea temperature and quick removal of oil from most of the beaches (De la Huz et al., 2005; Junoy et al., 2005).

Six months after the spill, O Rostro beach suffered a severe reduction in macroinfaunal abundance and species number (1995 vs 2003). However, interannual variations throughout the period 2004-2007 did not show strong differences in macroinfauna assemblage structure. The beach recovery has also been detected with the AMBI.

The 'Prestige' oil spill affected the beach macroinfauna for the first 17-18 months. Ecological studies on interannual variations are scarce on Spanish coasts, and are crucial to determine variations of macroinfaunal assemblages. 
Moreover, ecological responses to climate change, such as shifts in physiology, phenology, distribution, assemblage structure and species interaction, are still uncertain, but apparently are increasing on sandy beaches throughout the last decades (Brown \& McLachlan, 2002; Jones et al., 2007).

Natural disturbances have possibly hindered the identification of the generalized effects of oil-related activities on macrofauna assemblages in the northern Gulf of Mexico (Green \& Montagna, 1996). Thus, the responses of opportunists to natural and anthropogenic disturbances are not easily distinguishable (Clark, 1982; Spies, 1987; HernándezArana et al., 2005).

\section{ACKNDWLEDGEMENTS}

We are grateful to Dr Mariano Lastra (Universidad de Vigo, Spain) who kindly provided data from 1995. The authors wish to thank the Benthos Team from Universidad de Alcalá ('The Cribians') for field assistance.

\section{FINANCIAL SUPPDRT}

This research was supported by Project VEM2004-08544, Spanish Ministerio de Educación y Ciencia and the Project 'Biodiversidad marina en el Atlántico', Instituto Frankin Universidad de Alcalá.

\section{REFERENCES}

Anderson M.J. (2005) PERMANOVA: a FORTRAN computer program for permutational multivariate analysis of variance. Department of Statistics, University of Auckland, New Zealand, 24 pp.

Bernabeu A.M., Nuez de la Fuente N., Rey D., Rubio B., Vilas F. Medina R. and González M.E. (2006) Beach morphodynamics forcements in oiled shorelines: coupled physical and chemical processes during and after fuel burial. Marine Pollution Bulletin 52, 1156-1168.

Borja Á., Franco J. and Pérez V. (2000) A marine biotic index to establish the ecological quality of soft-bottom benthos within European estuarine and coastal environments. Marine Pollution Bulletin 40, 11001114 .

Borja Á., Muxika I. and Franco J. (2003) The application of a Marine Biotic Index to different impact sources affecting soft-bottom benthic communities along European coasts. Marine Pollution Bulletin 46, 835-845.

Bray J.R. and Curtis J.T. (1957) An ordination of upland forest communities of southern Wisconsin. Ecological Monographs 27, 325-349.

Brazeiro A. and Defeo O. (1996) Macroinfauna zonation in microtidal sandy beaches: is it possible to identify patterns in such variable environments? Estuarine, Coastal and Shelf Science 42, 523-536.

Brown A.C. and McLachlan A. (2002) Sandy shore ecosystems and the threats facing them: some predictions for the year 2025. Environmental Conservation 29, 62-77.

Buchanan J.B. (1984) Sediment analysis. In Holme N.A. and McIntyre A.D. (eds) Methods for the study of marine benthos. Oxford: Blackwell Scientific, pp. 41-65.

CEPRECO (Centro para la Prevención y Lucha contra la Contaminación Marítima y del Litoral) (2006) Contaminación de las playas por derrame de hidrocarburos: influencia de la dinámica marina. Madrid: Ministerio de la Presidencia, $130 \mathrm{pp}$.
Clark R.B. (1982) The long-term effect of oil pollution on marine populations, communities and ecosystems: some questions. Philosophical Transactions of the Royal Society of London, B 297, 185-192.

Clarke K.R. and Gorley R.N. (2006) PRIMER v. 6: user manual/tutorial. Plymouth: PRIMER-E.

Clarke K.R. and Green R.H. (1988) Statistical design and analysis for a 'biological effects' study. Marine Ecology Progress Series 46, 213-226.

De la Huz R., Lastra M., Junoy J., Castellanos C. and Viéitez J.M. (2005) Biological impacts of oil pollution and cleaning in the intertidal zone of exposed sandy beaches: preliminary study of the 'Prestige' oil spill. Estuarine, Coastal and Shelf Science 65, 19-29.

Emery K.O. (1961) A simple method of measuring beach profiles. Limnology and Oceanography 6, 90-93.

Feder H.M. and Blanchard A. (1998) The deep benthos of Prince William Sound, Alaska, sixteen months after the Exxon Valdez oil spill. Marine Pollution Bulletin 36, 118-130.

Fukuyama A.K., Shigenaka G. and VanBlaricom G.R. (1998) Oil spill impacts and the biological basis for response guidance: an applied synthesis of research on three subarctic intertidal communities. NOAA Technical Memorandum NOS ORCA 125, Hazardous Materials Response and Assessment Division, National Oceanic and Atmospheric Administration, Seattle, 73 pp.

Gómez-Gesteira J.L. and Dauvin J.C. (2000) Amphipods are good bioindicators of the impact of oil-spills on soft-bottom macrobenthic communities. Marine Pollution Bulletin 40, 1017-1027.

Gómez-Gesteira J.L. and Dauvin J.C. (2005) Impact of the Aegean Sea oil spill on the subtidal fine sand macrobenthic community of the Ares-Betanzos Ría (Northwest Spain). Marine Environmental Research 60, 289-316.

Gómez-Gesteira J.L., Dauvin J.C. and Salvande-Fraga M. (2003) Taxonomic level for assessing oil-spill effects on soft-bottom sublittoral benthic communities. Marine Pollution Bulletin 46, 562-572.

González M., Medina R., Bernabeu A.M. and Novóa X. (2009) Influence of beach morphodynamics in the deep burial of fuel in beaches. Journal of Coastal Research 25, 799-818.

Green R.H. and Montagna P. (1996) Implications for monitoring study designs and interpretation of results. Canadian Journal of Fisheries Aquatic Sciences 53, 2629-2636.

Hernández-Arana H.A., Warwick R.M., Attrill M.J., Rowden A.A. and Gold-Bouchot G. (2005) Assessing the impact of oil-related activities on benthic macroinfauna assemblages of the Campeche shelf, southern Gulf of Mexico. Marine Ecology Progress Series 289, 89-107.

Jaramillo E. (1994) Patterns of species richness in sandy beaches of South America. South African Journal of Zoology 29, 227-234.

Jaramillo E., McLachlan A. and Coetzee P. (1993) Intertidal zonation patterns of macroinfauna over a range of exposed sandy beaches in south-central Chile. Marine Ecology Progress Series 101, 105-118.

Jones A.R., Gladston Q. and Hacking N.J. (2007) Australian sandybeach ecosystems and climate change: ecology and management. Australian Zoologist 34, 190-202.

Jones D.A. and Pierpoint C.J. (1997) Ecology and taxonomy of the genus Eurydice (Isopoda: Cirolanidae) from sand beaches on the Iberian peninsula. Journal of the Marine Biological Association of the United Kingdom 77, 55-76.

Junoy J., Castellanos C., Viéitez J.M., de la Huz M.R. and Lastra M. (2005) The macroinfauna of the Galician sandy beaches (NW Spain) affected by the Prestige oil-spill. Marine Pollution Bulletin 50, 526536. 
Junoy J. and Viéitez J.M. (1992) Macrofaunal abundance analyses in the Ría de Foz (Lugo, Northwest Spain). Cahiers de Biologie Marine 33, $331-345$.

Kingston P.F., Dixon I.M.T., Hamilton S. and Moore D.C. (1995) The impact of the Brauer oil-spill on the macrobenthic infauna of the sediments off the Shetland Islands. Marine Pollution Bulletin 30, 445-459.

Kruskal J.B. and Wish M. (1978) Multidimensional scaling. Beverly Hills CA and London: Sage Publications (Sage University Paper series on Quantitative Application in the Social Sciences, 07-011)

Laborda A.J. (1987) Autoecología de la macrofauna de la playa de Covas. II. Poliquetos sedentarios. Boletín del Instituto Español de Oceanografía 4, 47-6o.

Lastra M., de la Huz R., Sánchez-Mata A.G., Rodil I.F., Aerts K., Beloso S. and López J. (2006) Ecology of exposed sandy beaches in northern Spain: environmental factors controlling macrofauna communities. Journal of Sea Research 55, 128-140.

McLachlan A. (1983) Sandy beach ecology. A review. In McLachlan A. and Erasmus T. (eds) Sandy beaches as ecosystems. The Hague: Junk, pp. $321-380$.

McLachlan A. (1990) Dissipative beaches and macrofauna communities on exposed intertidal sands. Journal of Coastal Research 6, 57-71.

McLachlan A. and Dorvlo A. (2005) Global patterns in sandy beach macrobenthic communities. Journal of Coastal Research 21, 674-687.

McLachlan A. and Jaramillo E. (1995) Zonation on sandy beaches Oceanography and Marine Biology: an Annual Review 33, 305-335.

Peterson C.H. (2001) The 'Exxon Valdez' oil spill in Alaska: acute, indirect and chronic effects on the ecosystem. Advances in Marine Biology $39,1-103$.

Pielou E.C. (1975) Ecological diversity. New York: Wiley.

Pollock L.W. and Hummon W.D. (1971) Cyclic changes in interstitial water content, atmospheric exposure and temperature in a marine beach. Limnology and Oceanography 16, 522-535.

Puente A., Juanes J.A., Calderón G., Echavarri-Erasun B., García A. and García-Castrillo G. (2009) Medium-term assessment of the effects of the Prestige oil spill on estuarine benthic communities in Cantabria (Northen Spain, Bay of Biscay). Marine Pollution Bulletin $58,487-495$.
Puente A., Juanes J.A., García A., Álvarez C., Revilla J.A. and Carranza I. (2008) Ecological assessment of soft bottom benthic communiteis in northern Spanish estuaries. Ecological Indicators 8, 373-388.

Salvat B. (1964) Les conditions hydrodynamiques interstitielles des sédiments meubles intertidaux et la repartition verticale de la faune endogée. Comptes Rendus Hebdomadaires des Séances de l'Académie des Sciences 259, 1575-1964.

Salvat B. (1967) La macrofaune carcinologique endogée des sédiments muebles intertidaux (Tanaidacea, Isopodes et Amphipodes), ethologie, bionomie et cycle biologique. Mémoires du Muséum National d'Histoire Naturelle, Ser. A, Zoologie XLV, 275 pp.

Serrano A., Sánchez F., Preciado I., Parra S. and Frutos I. (2006) Spatial and temporal changes in benthic communities of thte Galician continental shelf after the Prestige oil spill. Marine Pollution Bulletin 53, 315-331.

Short A.D. (1999) Handbook of beach and shoreface morphodynamics. London: John Wiley, $379 \mathrm{pp}$.

Souza J.R.B. and Borzone C.A. (2000) Population dynamics and secondary production of Scolelepis squamata (Polychaeta: Spionidae) in an exposed sandy beach of southern Brazil. Bulletin of Marine Science $67,221-233$.

Spies R.B. (1987) The biological effects of petroleum hydrocarbons in the sea: assessments from the field and microcosms. In Boesch D.F. and Rabalais N.N. (eds) Long-term environmental effects of offshore oil and gas development. London: Elsevier Applied Science, pp. 411-467.

SPSS (1999) Statistical package of the social sciences, vol. 10.o. Chicago, IL: SPSS Inc.

Tabachnick B.G. and Fidell L.S. (2001) Using multivariate statistics. 4th edition. Needham Heights, MA: Allyn \& Bacon.

and

Underwood A.J. (1991) Beyond BACI: experimental designs for detecting human impacts on temporal variations in natural populations. Australian Journal of Marine and Freshwater Research 42, 569-587.

\section{Correspondence should be addressed to:}

J. Junoy

Departamento de Ciencias de la Vida, Universidad de Alcalá E-28871 Alcalá de Henares, Spain email: juan.junoy@uah.es 